\title{
NFIL3 wt Allele
}

National Cancer Institute

\section{Source}

National Cancer Institute. NFIL3 wt Allele. NCI Thesaurus. Code C84452.

Human NFIL3 wild-type allele is located in the vicinity of 9q22 and is approximately $15 \mathrm{~kb}$ in length. This allele, which encodes nuclear factor interleukin-3-regulated protein, is involved in the regulation of gene transcription. 